\title{
Intercropping Pineapple With Rice or Cowpea: An Alternative for Family Farming in the State of Tocantins, Brazil
}

\author{
S. C. Siebeneichler ${ }^{1}$, E. R. Santos ${ }^{2}$, R. A. Veloso ${ }^{3}$, M. A. B. Pereira ${ }^{4}$, R. F. F. Brito ${ }^{5}$ C. M. Souza ${ }^{1}$, F. N. Oliveira ${ }^{6}$, \\ J. Barilli ${ }^{1} \&$ M. M. C. Ribeiro \\ ${ }^{1}$ Federal University of Tocantins, Campus of Gurupi, Tocantins, Brazil \\ ${ }^{2}$ Faculdade da Amazônia, Vilhena, Rondônia, Brazil \\ ${ }^{3}$ Faculdade Metropolitana de Anápolis, Anápolis, Goiás, Brazil \\ ${ }^{4}$ University of Gurupi, Tocantins, Brazil \\ ${ }^{5}$ Federal Institute of Tocantins, Campus Colinas of Tocantins, Tocantins, Brazil \\ ${ }^{6}$ Colégio Estadual João Tavares Martins, Araguaçu, Tocantins, Brazil \\ ${ }^{7}$ AGRO Projetos e Consultorias, Gurupi, Tocantins, Brazil
}

Correspondence: S. C. Siebeneichler, Federal University of Tocantins, Campus of Gurupi, Tocantins, Brazil. Tel: 55-63-3311-1632. E-mail: susana@mail.uft.edu.br

Received: December 17, 2018

Accepted: January 21, 2019 Online Published: March 15, 2019

doi:10.5539/jas.v11n4p288

URL: https://doi.org/10.5539/jas.v11n4p288

\begin{abstract}
Pineapple is commonly planted in monoculture systems. It is a long-cycle crop that takes time to monetize, which hinders its cropping by small farmers. The objective of this work was to evaluate the production and quality of pineapple with short-cycle crops, at the beginning of the growing period, as an alternative for family farming in the state of Tocantins. The experimental design was randomized complete block with three treatments and four replications. The pineapple was intercropped with rice and cowpea. The treatments consisted of T1: pineapple + rice; T2: pineapple + cowpea and T3: pineapple in monoculture. The evaluated variables of the pineapple fruit were $\mathrm{pH}$, soluble solids, titratable acidity, yield, fruit mass, fruit length with crown, fruit length without crown and fruit circumference. For the rice and cowpea, the yield and the Area Equivalence Index (AEI) were determined. The cropping system did not influence the pineapple fruits quality. The pineapple yielded less. Cowpea yielded more when intercropped with pineapple. The AEI of the pineapple + rice intercropping was 2.07, being feasible for increasing the use of the area by $100 \%$. The AEI of the pineapple + cowpea intercropping was 2.48 , being feasible as it increased the use of the area by $148 \%$. The results obtained showed that it is possible to intercrop pineapple with rice or cowpea at the beginning of pineapple cultivation, and it can be a viable alternative for family farming.
\end{abstract}

Keywords: Ananas comosus, Oryza sativa, Vigna unguiculata, subsistence

\section{Introduction}

The pineapple is commonly grown in a monoculture system, but is also used by small farms, in family farming system. As it is a long-cycle crop, the economic return also occurs in the long term, which ends up hampering the cultivation by small farmers who make limited use of mechanization on their properties and require complementary incomes during the crop implantation phase. Thus, intercropping pineapple with other crops of economic interest may be a viable alternative, therewith, maximizing the use of environmental resources and labor is fundamental, especially for the sustainability of family farming (Asten et al., 2011). Intercropping also increases income and improves soil properties. These systems have sought not only to increase the production and yield of the cultivated products, but also to adopt production systems that better adapt to the ecological and socioeconomic conditions of certain regions (Cordeiro et al., 2009; Albuquerque et al., 2012; Maciel et al., 2013). When intercropped, crops will always compete for water, nutrient, light and other factors that are directly linked to the plant development. The competition depends on the species involved, their root systems and the availability of water, nutrients and oxygen (Costa \& Silva, 2008). According to Cunha (2004), the second crop must have good acceptance in the regional commerce and allow the good development of the pineapple. 
Cunha and Reinhardt (2004), and Cunha et al. (2005) mention that pineapple is a crop that is easily adapted to intercropping systems, due to its slow initial growth and to the double-row planting system. In Tocantins state, the spacings adopted between the double-rows are larger than those used in other regions and the soil remains uncovered in the first six months of the crop implantation during the rainy season. Intercropping pineapple with short-cycle crops can enable small local farmers to sustainably produce pineapple. Rice and cowpea were chosen as secondary crops because of their importance in subsistence agriculture in Brazil, with the main grains consumed in the Brazilian diet. In this way, the objective of this work was to evaluate the pineapple production and quality intercropped with rice or cowpea, at the beginning of the growth cycle.

\section{Method}

The experiment was conducted from January 2008 to June 2009, at a family farm near Gurupi, Tocantins, Brazil, located at $11^{\circ} 51^{\prime} 58^{\prime \prime} \mathrm{S}$ and $48^{\circ} 59^{\prime} 17^{\prime \prime} \mathrm{W}$, at $287 \mathrm{~m}$ of altitude.

According to the Köppen classification, the local climate is type B1wA'a 'humid, with moderate water deficiency. The average annual temperature varies from 22 to $32{ }^{\circ} \mathrm{C}$, with average relative air humidity around $76 \%$ and an average annual rainfall of $1400 \mathrm{~mm}$.

The experimental design was a randomized complete block with three treatments and four replications. The treatments tested were: T1: Pineapple + rice; T2: Pineapple + cowpea and T3: Pineapple in monoculture. Three replications were performed for pineapple fruit quality traits.

The pineapple variety was 'Pérola'. The second crops cultivars adopted were: rice 'BRS Spring', recommended for uplands (Embrapa, 2013); and cowpea 'Vinagre', which presents medium cycle, prostrate habit, indeterminate growth and red color grains, with great economic and cultural value in the State of Tocantins, being cultivated mainly in family agriculture.

Soil correction was performed based on the soil analysis and the fertilizers were applied individually by crop, following the regional recommendations. The planting of pineapple and the second crops was carried out together in January 2008. The pineapple was planted in double-rows with the following spacing: $1.80 \times 0.50 \times$ $0.40 \mathrm{~m}$. The rice and cowpea were sown between the double rows according to the spacings adopted for each crop in the region. Weed control was performed manually when necessary. The experiment was not irrigated.

Harvesting of the rice and cowpea was carried out in April/May 2008, and pineapple floral induction and harvest were carried out in January and June 2009, respectively. The following variables were evaluated: a) pH; Soluble solids (SS; $\left.{ }^{\circ} \mathrm{BRIX}\right)$; b) titratable acidity (TA,\%); c) yield $\left(\mathrm{t} \mathrm{ha}^{-1}\right)$; d) fruit mass $\left.(\mathrm{g}) ; \mathrm{e}\right)$ crownless fruit length (CFL; $\mathrm{cm})$; f) fruit length with crown (FLC; $\mathrm{cm}) ; \mathrm{g}$ ) fruit circumference (CIRC; $\mathrm{cm}$ ); h) cowpea yield and $\mathrm{h}$ ) rice yield.

The pineapple fruits were weighted on a digital scale and measured for class determination (length and diameter). Each fruit was peeled, chopped and crushed to obtain the juices used for the physicochemical analysis. The $\mathrm{pH}$ was determined using a table $\mathrm{pH}$ meter; the soluble solids (SS) contents with portable refractometer; and the titratable acidity (AT ) by titration with $0.1 \mathrm{M} \mathrm{NaOH}$ solution, being the result expressed as $\%$ of citric acid.

To determine the cowpea yield, the pods were harvested as they matured. For rice yield, the panicles were harvested at maturity. Both cowpea and rice had their samples weighted on a digital scale and the values transformed in ton per hectare.

The data were submitted to analysis of variance $(\mathrm{p}<0.05)$ test $\mathrm{F}$. The means were compared by the Tukey test. Individual analyzes of variance were also performed for single and intercropped systems for rice and cowpea; the means were compared by the Tukey test at $(\mathrm{p}<0.05) \mathrm{F}$ test.

For the intercropped treatments, the area equivalence index (AEI) was determined using the formula: AEI $($ pineapple + rice $)=($ intercropped pineapple yield/pineapple yield in monoculture $)+($ intercropped rice yield/rice in the monoculture) and AEI (pineapple + cowpea) (intercropped pineapple yield/pineapple yield in monoculture) + (intercropped cowpea yield/cowpea yield in monoculture). The intercropping is considered efficient when the AEI is higher than 1.0 and harmful to production when less than 1.0 (Teixeira et al., 2011).

\section{Results and Discussion}

\subsection{Fruit Quality of Intercropped Pineapple}

The intercropping did not interfere with the pineapple fruits quality (Table 1) and (Figure 1). No difference was observed between the values of $\mathrm{pH}$, soluble solids and titratable acidity between the monoculture crop and the intercropping conditions. The values found are within the established standards for the state of Tocantins according to Conceição et al. (2004), except for the titratable acidity that presented slight lower values. 
Table 1. Analysis of variance of pineapple fruit quality-pH, SS; ${ }^{\circ} \mathrm{BRIX}$ and TA $(\%)$ in a intercropping system with rice, cowpea, and monoculture. Gurupi-TO, Brazil

\begin{tabular}{lllll}
\hline \multirow{2}{*}{ SV } & \multirow{2}{*}{ DF } & \multicolumn{3}{c}{ Average square } \\
\cline { 3 - 5 } & & $\mathrm{pH}$ & $\mathrm{SS}^{\circ} \mathrm{BRIX}$ & $\mathrm{TA}(\%)$ \\
\hline Treatment & 2 & $0.000011^{\mathrm{ns}}$ & $0.253333^{\mathrm{ns}}$ & $0.000078^{\mathrm{ns}}$ \\
Block & 2 & $0.000078^{\mathrm{ns}}$ & $1.720000^{\mathrm{ns}}$ & $0.000144^{\mathrm{ns}}$ \\
Error & 4 & 0.000178 & 0.173333 & 0.000261 \\
\hline Mean & & 3,76 & 14,60 & 0.61 \\
CV $(\%)$ & & 0.35 & 0.17 & 0.75 \\
\hline
\end{tabular}

Note. ${ }^{\mathrm{ns}}$ not significant by the F test.

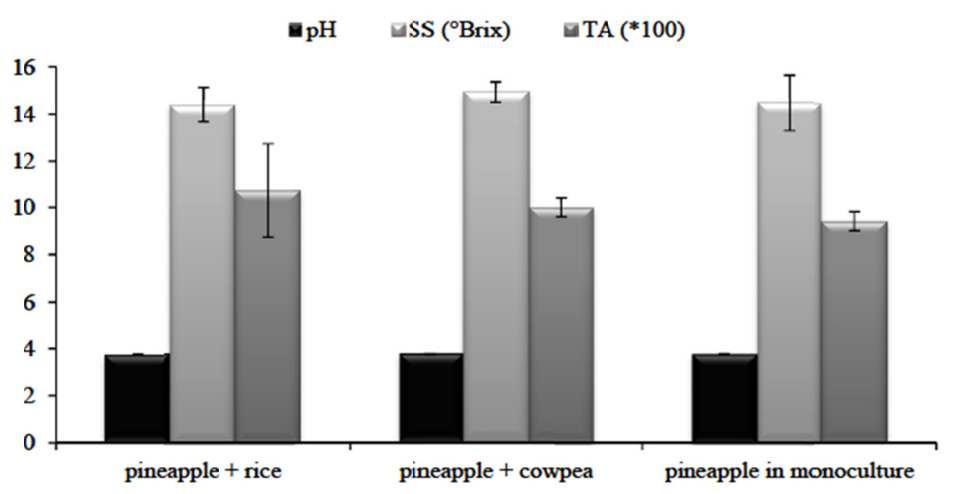

Figure 1. Pineapple fruits quality characteristics in a system of intercropping with rice, cowpea, and monoculture. Gurupi-TO, Brazil

\subsection{Agronomic Characteristics of Intercropped Pineapple}

There was a significant difference between the cultivation systems adopted for pineapple for all evaluated variables, except crownless fruit length (CFL) (Table 2). These results demonstrate that the pineapple responded to cropping systems for fruit weight (FW), fruit length with crown (FLC), fruit circumference (Circ) and yield.

Table 2. Analysis of variance of the agronomic variables of pineapple 'Pérola' in monoculture and intercropping system with rice and cowpea, Gurupi-Tocantins, Brazil

\begin{tabular}{lllllll}
\hline \multirow{2}{*}{ SV } & \multirow{2}{*}{ DF } & \multicolumn{5}{c}{ Average square } \\
\cline { 3 - 6 } & & FW $(\mathrm{g})$ & FLC $(\mathrm{cm})$ & CFL $(\mathrm{cm})$ & Circ. $(\mathrm{cm})$ & Yield $\left(\mathrm{t} \mathrm{ha}^{-1}\right)$ \\
\hline Treatment & 2 & $114483.73^{*}$ & $147.72^{*}$ & $1.826^{\mathrm{ns}}$ & $9.320^{*}$ & $22.798^{*}$ \\
Block & 3 & $10775.12^{\mathrm{ns}}$ & $5.70^{\mathrm{ns}}$ & $0.336^{\mathrm{ns}}$ & $0.896^{\mathrm{ns}}$ & $2.154^{\mathrm{ns}}$ \\
Error & 6 & 12890.32 & 13.76 & 0.917 & 1.537 & 2.567 \\
\hline Mean & & 941.38 & 42.34 & 6.83 & 32.72 & 13.98 \\
CV $(\%)$ & 11.46 & 8.76 & 6.83 & 3.79 & 11.46 \\
\hline
\end{tabular}

Note. * Significant at $\mathrm{p} \leq 0.05 ;{ }^{\mathrm{ns}}$ not significant.

FW: Fruit weight; FLC: Fruit with crown; CFL: crownless fruit length; Circ.: Fruit circumference.

Intercropping with annual plants at the beginning of the pineapple cultivation did not decrease the fruit circumference and its length without the crown. However, a decrease of the length of the fruit with the crown was observed, which was lower for pineapple plants intercropped with cowpea (Figure 2). 


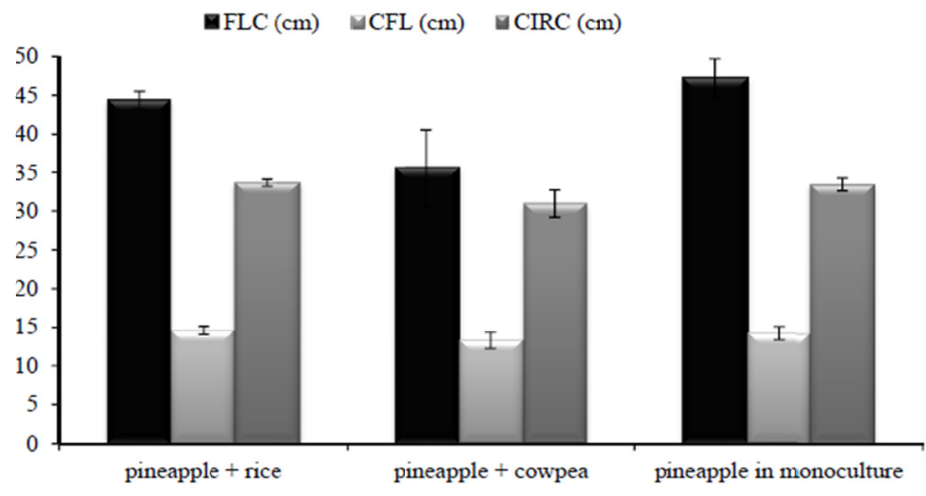

Figure 2. Fruit length with and without crown and circumference of pineapple fruits in the intercropping system with rice, cowpea, and monoculture. Gurupi-TO, Brazil

\subsection{Agronomic Characteristics of Pineapple Intercropped With Rice}

Intercropping pineapple with rice did not reduce the fruit mass and the yield. This response is probably related to the architecture of the rice plants (vertical) and its lower aggressiveness, so that the pineapple plants could develop satisfactorily without competition for light and nutrients in the soil in the initial phase of development (Figure 3).

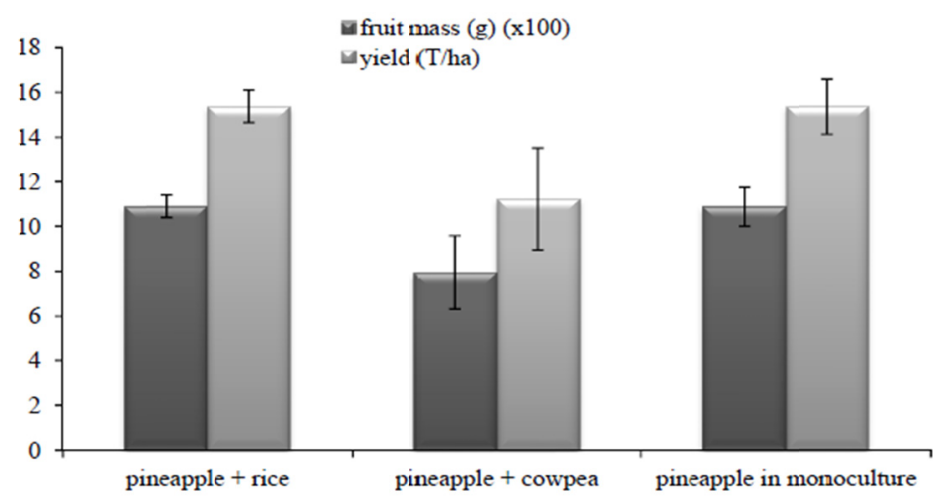

Figure 3. Fruit weight and yield of pineapple in the intercropped system with rice, cowpea, and monoculture.

Gurupi-TO, Brazil

\subsection{Agronomic Characteristics of Pineapple Intercropped With Cowpea}

Intercropping pineapple and cowpea at the beginning of the cycle reduced the mass of the pineapple fruit and, consequently, also the yield, demonstrating that the intercropping with cowpea did not provide good performance, reducing the pineapple productive potential. This reduction can be justified by the aggressiveness of the cowpea and the planting system, since two rows of the cowpea were planted between the double rows of the pineapple. Cowpea presents undetermined and rapid growth, with long and climbing branches, projecting its branches into the pineapple double-rows, which may have promoted competition with the main crop.

These results differ from Karanja et al. (2014) who observed lower development and yield of cowpea when it was intercropped with sorghum in Kenya, Africa, and from Santos et al. (2014) that obtained lower cowpea yield when intercropped with maize, in Tocantins, Brazil.

According to Aguiar et al. (2011), the pineapple yield reduction can be associated with plant density, since competition for light occurs. Higher plant densities may cause self-shading, reducing light availability and decreasing photosynthetic activity (Santos et al 2014). One alternative could be the use of a single-row of cowpea between the double-row pineapple, thus, the competitive effect between the two crops may be attenuated.

A negative effect of intercropping pineapple with cowpea was also observed by Souza et al. (2010) with banana cropping, where the intercropping promoted a delay in the production cycle of the crop. The authors argued that cowpea present indeterminate and fragile growth plant, with greater soil cover, in intensity and time, which may 
have caused competition with the banana plants. The same was observed in our experiment, so probably the competition was the reason that fruit weight and yield of pineapple in the intercropped system was lower.

\subsection{Area Equivalence Indices (AEI)}

The yield means and individual relative index (AI) and area equivalence indexes (AEI) for pineapple, rice and bean crops in single and intercropping are shown in Table 3.

The rice yield did not differ significantly between the cropping systems studied. However, cowpea was yielded better when intercropped with pineapple, possibly because cowpea is more rustic and benefited from the pineapple fertilization. According to Barreiro Neto et al. (2017), in an intercropping system, plants compete mainly for light, water and nutrients.

Table 3. Mean test for yield and relative individual index (AI) and area equivalence indexes (AEI), calculated based on yield of crops grown in Gurupi-Tocantins, Brazil

\begin{tabular}{|c|c|c|c|}
\hline Cropping system & Prod. $\left(\mathrm{t} \mathrm{ha}^{-1}\right)$ & AI & AEI \\
\hline \multicolumn{4}{|l|}{ Pineapple } \\
\hline Pineapple & $15.35 \mathrm{a}$ & - & - \\
\hline Pineapple + Rice & $15.38 \mathrm{a}$ & 1.00 & $2.07^{\prime \prime}$ \\
\hline Pineapple + Cowpea & $11.23 \mathrm{~b}$ & 0.73 & 2.48 \\
\hline$C V(\%)$ & 14 & & \\
\hline \multicolumn{4}{|l|}{ Rice } \\
\hline Rice & $2.65 \mathrm{a}$ & - & - \\
\hline Rice + Pineapple & $2.84 \mathrm{a}$ & 1.07 & - \\
\hline$C V(\%)$ & 20 & & \\
\hline \multicolumn{4}{|l|}{ Cowpea } \\
\hline Cowpea & $1.00 \mathrm{~b}$ & - & - \\
\hline Cowpea + Pineapple & $1.75 \mathrm{a}$ & 1.75 & - \\
\hline $\mathrm{CV}(\%)$ & 25 & & \\
\hline
\end{tabular}

Note. * The intercropping is considered efficient when the AEI is greater than 1.0 and harmful to production when less than 1.0

The area equivalence indexes (IEA) (Table 3) were 2.07 for pineapple + rice and 2.48 for the pineapple + cowpea, indicating the efficiency of intercropping. However, single cropping required $100 \%$ and $148 \%$ more of planted area for rice and cowpea, respectively, to equate the yield obtained in intercropping with pineapple.

The AEI, although positive, should not be considered sufficient for a decision making (Moura, 1984). The yield of each crop component of the intercropping should be taken into account. In this case, both rice and cowpea appeared to be suitable for planting in intercropping with pineapple, under the soil and climatic conditions of Gurupi, Tocantins, Brazil.

The results obtained in the present work demonstrated that there is a possibility of intercropping pineapple at the beginning of its cultivation with rice, being a viable alternative for family farming.

\section{Conclusions}

The cropping system did not influence the pineapple fruits quality but reduced the yield when was intercropped with cowpea.

The intercropping pineapple + rice is the best cropping system.

The cropping system with pineapple and rice or cowpea is viable for family farming.

The AEI of the intercropping pineapple + rice was 2.07 , being viable as it increases the use of the area by $100 \%$.

The AEI of the intercropping pineapple + cowpea was 2.48 , being viable as it increased the use of the area by $148 \%$.

\section{Acknowledgements}

The study was supported financially by Secretaria de Ciencia e Tecnologia/Conselho Nacional de Desenvolvimento Científico e Tecnológico (SECT/CNPq-PROC 20072029 0021). The authors are indebted to Mrs. Maria Albertisa Rodrigues Peixoto, a family farmer, for lending the area to the planting and for taking care of the experiment with us. 


\section{References}

Aguiar, E. B., Valle, T. L., Lorenzi, J. O., Kanthack, R. A. D. Miranda Filho, H., \& Granja, N. do P. (2011). Efeito da densidade populacional e época de colheita na produção de raízes de mandioca de mesa. Bragantia, 70, 561-569. https://doi.org/10.1590/S0006-87052011000300011

Asten, P. J. A. van, Wairegi, L. W. I., Mukasa, D., \& Uringi, N. O. (2011). Agronomic and economic benefits of coffee-banana intercropping in Uganda's smallholder farming systems. Agricultural Systems, 104, $326-334$. https://doi.org/10.1016/j.agsy.2010.12.004

Barreiro Neto, M., Franco, C. F. O., Leite. G. M., Arriel, N. H. C., \& Santos, E. S. (2017). Valoração de custo e rentabilidade econômica de sistema de produção de feijão fava de crescimento determinado na paraibana. Tecnologia e Ciencia Agropecária, 11, 75-83.

Conceição, C. M., Spindler, T. S., Abadio, F. D. B., Fernandes, N. S., \& Coelho, A. F. S. (2004). Caracterização físico-química do abacaxi (Ananas comosus) cv. Pérola produzida no Estado do Tocantins. Congresso Brasileiro de Ciência e Tecnologia de Alimentos, 19, 2004, Recife. Anais... Recife: SBCTA.

Cordeiro, A. C. C., Maciel, F. C., \& Alves, A. B. (2009). Dendê em Roraima. Informações técnicas para a implantação de lavoura de dendê em Roraima. Roraima: Embrapa Roraima.

Costa, A. S. V., \& Silva, M. B. (2008). Sistemas de consórcio milho feijão para a região do Vale do Rio Doce, Minas Gerais. Ciência e Agrotecnologia, 32, 663-667. https://doi.org/10.1590/S1413-70542008000200050

Cunha, G. A, P. da. (2004). Cultivo do abacaxizeiro-Consorciação e Rotação de culturas (Circular Técnica 108). Embrapa Mandioca e fruticultura, Cruz das Almas-BA. Retrieved from http://200.128.102.2/ publicacoes/comunicados/comunicado_108.pdf

Cunha, G. A. P. Da., Reinhardt, D. H. R. C., \& Matos, A. P. (2005). Recomendações técnicas para o cultivo do abacaxizeiro (Circular Técnica 73). Retrieved from http://www.cnpmf.embrapa.br/publicacoes/circulares/ circular_73.pdf

Cunha, G. A. P. Da, \& Reinhardt, D. H. R. C. (2004). Orientações Básicas para o Cultivo do Abacaxizeiro (Circular Técnica 110). Retrieved from http://www.cnpmf.embrapa.br/publicacoes/comunicados/comunica do_110.pdf

Embrapa. (2013). Catalog of rice cultivars. Embrapa, Brazil. Retrieved from https://www.cnpaf.embrapa.br/ transferencia/tecnologiaseprodutos/cultivares/catalogoArroz-17Dez2013.pdf

Karanja, S. M., Kibe, A. M., Karogo, P. N., \& Mwangi, M. (2014). Effects of intercrop population density and row orientation on growth and yields of sorghum-cowpea cropping systems in semi-arid Rongai, Kenya. Journal of Agricultural Science, 6, 34-43. https://doi.org/10.5539/jas.v6n5p34

Maciel, F. C. S., Cordeiro, A. C. C., Lima, A. C. S., Correia, R G., Silva, W. L. M., \& Lopes, A. D. O. (2013). Desenvolvimento vegetativo de cultivares de palma de óleo dos 14 aos 34 meses de idade em ecossistemas de Roraima. Revista Agroambiente, 7, 304-312. https://doi.org/10.18227/1982-8470ragro.v7i3.1261

Moura, P. A. M. (1984). Alguns indicadores para análise econômica do consórcio feijão e milho. Informe Agropecuário, 10, 3-10.

Santos, E. R., Salgado, F. M., Santos, W. R., Ferraz, E. F., \& Silva, A. R. (2014). Consorciação de milho e feijão-caupi para produção de espigas verdes e grãos verdes em Tocantins. Nucleus, 11, 291-300. https://doi.org/10.3738/1982.2278.1032

Souza, I., Pereira, M. C. T., Ribeiro, R. C. F., Nietsche, S., Maia, V. M., \& Lemos, J. P. (2010). Plantio irrigado de bananeiras resistentes à sigatoka-negra consorciado com culturas anuais. Revista Brasileira de Fruticultura, 32, 172-180. https://doi.org/10.1590/S0100-29452010005000007

Teixeira, I. R., Silva, G. C., Timossi, P. C., \& Silva, A. G. (2011). Desempenho agronômico de cultivares de feijão-comum consorciado com mamona. Revista Caatinga, 24, 55-61.

\section{Copyrights}

Copyright for this article is retained by the author(s), with first publication rights granted to the journal.

This is an open-access article distributed under the terms and conditions of the Creative Commons Attribution license (http://creativecommons.org/licenses/by/4.0/). 